\title{
Genetic relationships among cultivated and wild bananas from East Kalimantan, Indonesia based on ISSR markers
}

\author{
WIDI SUNARYO ${ }^{1, \bullet}$, WAHIDA $^{1}$, SURIA DARMA IDRIS ${ }^{1}$, ANANDA NURYADI PRATAMA ${ }^{2,3}$, \\ KUMROP RATANASUT ${ }^{2,3}$, NURHASANAH ${ }^{1}$ \\ ${ }^{1}$ Department of Agroecotechnology, Faculty of Agriculture, Universitas Mulawarman. Jl. Pasir Balengkong, Kampus Gunung Kelua, Samarinda 75123, \\ East Kalimantan, Indonesia. Tel./fax.: +62-541-749352, 479314, "email: widi_sunaryo@yahoo.com \\ ${ }^{2}$ Department of Agricultural Sciences, Faculty of Agriculture, Natural Resources and Environment, Naresuan University. Phitsanulok, 6500, Thailand \\ ${ }^{3}$ Center of Excellence in Research for Agricultural Biotechnology, Naresuan University. Phitsanulok, 6500, Thailand
}

Manuscript received: 21 December 2019. Revision accepted: 27 January 2020.

\begin{abstract}
Sunaryo W, Wahida, Idris SD, Pratama AN, Ratanasut K, Nurhasanah. 2020. Genetic relationships among cultivated and wild bananas from East Kalimantan, Indonesia based on ISSR markers. Biodiversitas 21: 824-832. East Kalimantan is one of biodiversity centers for banana in Indonesia including wild or cultivated bananas. This biodiversity is long-historical genetically contributed by the existence of wild cultivars, local/indigenous varieties or introduced accessions from other regions in Indonesia. The existence of cultivated bananas has played an important role in the socio-economic significance of the local people. The genetic contribution of wild and local banana from East Kalimantan to the cultivated bananas or vice versa is very interesting to study. This research reported the genetic relationships among wild and cultivated bananas using Inter Simple Sequence Repeat (ISSR) markers. Thirteen wild and cultivated banana samples collected from different districts of East Kalimantan Province were analyzed using 15 primers of ISSR marker. ISSR primers generated 133 loci, of which 132 were polymorphic $(98.98 \%)$ with an average of 9.43 loci per primer. The ISSR marker is very effective and powerful to detect and discriminate the polymorphisms among cultivated and wild bananas. This is supported by PIC value which ranged from 0.60 to 0.91 per primer with an average of 0.80 per primer. The marker index (MI) values were ranged from 1.62 to 11.48 per primer. Primer UBC 855 produced the highest MI value which was 11.48 per primer and UBC 848 resulted in the lowest (1.62 per primer). The similarity coefficients ranged from 0.43 to 0.81 . The dendrogram constructed based on UPGMA divided the banana cultivars into 4 clusters, in which the first cluster comprised of the AA/AAA/AB genome bananas (Ambon, Kapas, Tembaga, Liar, and Tanduk). The second cluster composed of only Mauli Banana. The third cluster was comprised of six cultivated banana with AAB or ABB genome i.e., Raja, Rutai, Susu, Kepok, Awak, and Talas banana. The last cluster was only Klutuk Banana (BB genome). Wild bananas (Liar and Klutuk) was the ancestor of cultivated bananas since they contributed for A genome (Musa acuminate) and B genome (Musa balbisiana) to generate many triploid and cultivated bananas. Indigenous banana cultivars from Kalimantan, Rutai is closely related to Susu banana, while Talas banana is related to the AAB genome such as Raja, Rutai, Susu or ABB genome such as Awak and Kepok.
\end{abstract}

Keywords: East Kalimantan, genetic relationships, ISSR marker, wild and cultivated bananas

\section{INTRODUCTION}

Banana is a worldwide consumed fruit by people due to its nutritional values, affordable price and abundantly available in many regions. Asia, Australia, Middle, and South America are the centers of banana cultivation and cultivation is spreading to even Africa continent (Perrier et al. 2019). In Indonesia, banana has played an important role in the socio-economic-culture development from traditional market trade to food industries and greatly supports Indonesian food security and culture.

Borneo Island (Kalimantan), Indonesia is known as one of biodiversity centers including banana. The superior performance of a local variety from Kalimantan called Talas banana was reported (Sunaryo et al. 2017). Another endemic variety which has been historically used as special fruit for the king of Kutai Kertanegera kingdom referred as Rutai banana was also reported to show a unique taste and performance; although it is not extensively cultivated in East Kalimantan due to the low yield and production (Sunaryo et al. 2019). Both banana cultivars, Talas and
Rutai, have been morphologically studied to identify and classify their genome group compared to some local and commercial bananas cultivated in East Kalimantan (Sunaryo et al. 2019). Although many banana cultivars such as Kepok, Susu, Ambon, Mauli, Tanduk and Raja are widely cultivated as commercial bananas, but some wild and local cultivars such as Liar/Monyet, Klutuk, Awak, Tembaga, are also found in East Kalimantan with no or little use and cultivation.

The interaction between the commercial and wild bananas during their adaptation and development will result in the complex genetic composition of banana varieties. Natural interaction among wild and cultivated bananas through crossing and genetic mutations generates new hybrids and mutants that might contribute to generate superior varieties (Bakry et al. 2009). Thus, the genetic relationships and diversity among the cultivars are very important to be assessed to optimally use their genetic potentials for the breeding program, genetic conservation and to study their contribution to the socio-economic significances. 
Molecular markers have contributed significantly to plant breeding and improvement including in genetic mapping and plant diversity (Manzo-Sanchez et al. 2015). In addition, the use of molecular markers has been extending for validation of taxonomy and cultivar identification, genetic relationship studies, phylogenetic studies, tagging important traits, conducting linkage analysis, facilitating gene introgression through markerassisted selection, and estimating evolutionary and speciation events (Brown et al. 2017).

The polymerase chain reaction (PCR)-based DNA markers such as random amplified polymorphic DNA (RAPD), amplified fragment length polymorphism (AFLP) and simple sequence repeats (SSRs) or microsatellites are broadly used in the genetic studies of many crop plants. The benefit of the PCR-based DNA markers is the fast detection of genomic polymorphism of organisms compared to the non-PCR based such as restriction fragment length polymorphisms (RFLP) or microsatellite markers (Manzo-Sanchez et al. 2015; Ng and Tan 2015). However, the use of PCR-based DNA markers like RAPD is facing the limitation in terms of the low reproducibility and high cost especially for AFLP markers ( $\mathrm{Ng}$ and Tan 2015).

Inter simple sequence repeat (ISSR) is a PCR-based method marker considered as a simple, fast, effective and reproducible marker since it amplifies DNA segment located in between two identical microsatellite repeat regions oriented in opposite direction (Reddy et al. 2002; $\mathrm{Ng}$ and Tan 2015). ISSR markers could amplify and result in many loci for one primer since the inter-SSR regions are spread over and distributed throughout the genome of organisms (Reddy et al. 2002). Due to the many advantages of the ISSR markers compared to the other PCR-based DNA markers, the genetic study using this marker is extending throughout the plant species (Gebrehiwet et al. 2019; Ghimire et al. 2019; Ismail et al. 2019; Mohammadi and Bahramikia 2019), macroalgae (Cui et al. 2017), fungi (Kandan et al. 2016; Mitina et al. 2017; Anand and Kapoor 2018), and animal (Perez de Rosas et al. 2017; JassoMartinez et al. 2018; Gu et al. 2019).
The use of ISSR DNA-markers in the genetic diversity, relationships, dissimilarity, genetic stability study has been successfully applied in many plant species including banana. Many studies have shown the efficiency of the ISSR DNA-marker for various purposes in banana. The effectiveness of this marker for genetic relationship and diversity studies have been reported either for commercial (Venkatachalam et al. 2008; Marimutu Somasundaram et al. 2019) or wild bananas (Lamare and Rao 2015). In another hand, the genetic analysis of cultivated and wild banana from East Kalimantan based on molecular study is still very limited. This study is the first report of the use of ISSR DNA-markers applied for genetic relationships analysis among wild and cultivated bananas from East Kalimantan.

\section{MATERIALS AND METHODS}

\section{Plant materials}

Thirteen wild and cultivated bananas were used in this study comprising three wild bananas i.e., Liar, Awak, and Klutuk banana and ten cultivated bananas i.e., Ambon, Mauli, Raja, Susu, Kepok, Kapas, Tanduk, Tembaga, Rutai, and Talas (Table 1). The samples were collected from different geographical regions (districts) of East Kalimantan Province such as Samarinda, Kutai Kertanegara, Paser, and Penajam Paser Utara. Talas and Rutai are known as the local and indigenous banana from East Kalimantan (Sunaryo et al. 2019). All cultivars have belonged to different genome group classification such as AA, AAA, AB, AAB, ABB, and BB (Table 1).

\section{DNA extraction}

DNA sample was extracted from 0.2 grams of fresh and young banana leaf (Cigar leaf) using CTAB method (Doyle and Doyle 1987) with modifications. The use of liquid nitrogen for DNA grinding was omitted in this procedure. The DNA quantity and quality were measured and analyzed using a Nanodrop spectrophotometer (Thermo Scientific, USA) and gel electrophoresis visualization.

Table 1. The wild and cultivated bananas collected from different regions in East Kalimantan Province, Indonesia

\begin{tabular}{|c|c|c|c|c|}
\hline Banana variety & Species name & Plant information & Genome classification & $\begin{array}{l}\text { Collection site } \\
\text { (District) }\end{array}$ \\
\hline Liar & Musa acuminata & Wild & AA (Sunaryo et al. 2019) & Kutai Kertanegara \\
\hline Klutuk & Musa balbisiana & Wild & BB (Sunaryo et al. 2019) & Kutai Kertanegara \\
\hline Awak & Musa x paradisiaca & Wild & ABB (Orjeda 2000) & Penajam Paser Utara \\
\hline Ambon & Musa x paradisiaca & Cultivated & AAA (Sunaryo et al. 2019) & Samarinda \\
\hline Mauli & Musa x paradisiaca & Cultivated & $\mathrm{AAB}(\operatorname{Lim} 2012)$ & Samarinda \\
\hline Raja & Musa x paradisiaca & Cultivated & AAB (Lim 2012) & Samarinda \\
\hline Rutai & Musa x paradisiaca & Cultivated & AAB (Sunaryo et al. 2019) & Paser \\
\hline Susu & Musa x paradisiaca & Cultivated & AAB (Wahyuningtyas et al. 2009) & Samarinda \\
\hline Kepok & Musa x paradisiaca & Cultivated & $\mathrm{ABB}(\operatorname{Lim} 2012)$ & Kutai Kertanegara \\
\hline Talas & Musa x paradisiaca & Cultivated & AAB (Sunaryo et al. 2019) & Kutai Kertanegara \\
\hline Kapas & Musa x paradisiaca & Cultivated & AAB (Wahyuningtyas et al. 2009) & Penajam Paser Utara \\
\hline Tanduk & Musa x paradisiaca & Cultivated & AB (Sunaryo et al 2019) & Kutai Kertanegara \\
\hline Tembaga & Musa x paradisiaca & Cultivated & NR & Paser \\
\hline
\end{tabular}

Note: NR (No reference) 


\section{ISSR marker amplification}

Fifteen ISSR primers used in this study were referring from the previous reports (Table 2) mostly that has been applied in banana. PCR amplification was performed in a MiniAmp Plus Thermal Cycler PC 707. The PCR mixture contained $0.4 \mu \mathrm{l}$ of $0.2 \mathrm{mM}$ dNTPs, $2 \mu \mathrm{l}$ of 1 X PCR buffer, $0.6 \mu \mathrm{l}$ of $1.5 \mathrm{mM} \mathrm{MgCl} 2,0.2 \mu \mathrm{l}$ of 1 unit Taq DNA polymerase (Merck), $1 \mu \mathrm{l}$ of $30 \mu \mathrm{M}$ primers, $1 \mu \mathrm{l}$ DNA template (25-50 ng per $\mu \mathrm{l})$ and adjusted with distilled water to a total volume of $20 \mu \mathrm{l}$. The initial denaturation at $94^{\circ} \mathrm{C}$ for $5 \mathrm{~min}$ followed by 45 cycles of denaturation at $94^{\circ} \mathrm{C}$ for $30 \mathrm{sec}$, annealing at $43-53^{\circ} \mathrm{C}$ (depending on primer composition, Table 2) for $1 \mathrm{~min}$ and extension at $72^{\circ} \mathrm{C}$ for 2 min with a post extension at $72^{\circ} \mathrm{C}$ for 7 min was subjected to the PCR mixture.

\section{Gel electrophoresis}

The PCR amplification products were discriminated and run on $1 \%$ polymerized agarose in $1 \mathrm{x}$ Tris-AcetateEDTA (TAE) buffer for 40 min at 100 volts. DNA bands were stained with RedSafe $e^{\mathrm{TM}}$ and visualized on a UV transilluminator. The gel documentation system of BioRad, USA was applied to capture the figure of the electrophoresis gel profile. To measure the size of DNA bands, the O'GeneRuler Express DNA Ladder (Thermo Scientific, USA) was employed as marker.

\section{Data analysis}

The clearly reproducible and distinct bands produced from the gel electrophoresis for each primer were quantitatively scored from gel photographs for the ISSR analysis. The monomorphic and polymorphic bands were calculated. In each polymorphic band for each banana cultivar, the unit character was recorded in a binary matrix (' 0 ' for absence and ' 1 ' for presence) sheet. The binary data obtained from the marker systems were inputted in the NTSYS-pc 2.02 software (Rohlf 1998) to analyze the genetic similarities and relationships among the cultivars. Genetic similarity coefficient was calculated using Qualitative Similarity (SimQual) with a Simple Matrix (SM) method. The dendrogram representing genetic relationships among the cultivars was constructed by using the unweighted pair group method with arithmetic averages (UPGMA) algorithms with the Sequential Agglomerative Hierarchical Nested Cluster Analysis (SAHN). To describe the effectiveness and informativeness of the marker in detecting polymorphisms, the Polymorphic Information Content (PIC) was calculated using the formula PIC $=1$ $\Sigma \mathrm{pi}^{2}$, where pi is the frequency of the $\mathrm{i}^{\text {th }}$ allele (Sehgal et al. 2009). PIC values more than 0.50 indicate high polymorphisms information for each marker. The Effective Multiplex Ratio (EMR) was calculated as total number of polymorphic loci (per primer) multiplied by the proportion of polymorphic loci per their total number (formula; EMR= $\mathrm{np}(\mathrm{np} / \mathrm{n}), \mathrm{np}$ is total number of polymorphic loci, $\mathrm{n}$ is total number of loci). The higher the value of EMR, the more efficient the primer marker system is. The EMR values of each primer were used to determine the marker index values by multiplying it with their PIC values (formula: MI $=$ PIC $\mathrm{x}$ EMR). Marker index represents the total utility of the maker system (Varshney et al. 2007). The higher the value of MI, the more powerful/useful the marker system is.

Table 2. The ISSR primers, sequences and annealing temperatures used for genetic relationships study

\begin{tabular}{|c|c|c|c|c|}
\hline $\begin{array}{l}\text { Primer } \\
\text { name }\end{array}$ & $\begin{array}{l}\text { Primer } \\
\text { sequence }\end{array}$ & $\begin{array}{c}\text { GC } \\
\text { content } \\
(\%)\end{array}$ & $\begin{array}{c}\text { Anneling } \\
\text { temp. } \\
\left({ }^{\circ} \mathrm{C}\right)\end{array}$ & References \\
\hline UBC 808 & $(\mathrm{AG}) 8 \mathrm{C}$ & 53 & 47 & Das et al. (2018); Surabhi and Pttanayak (2015); Rout et al. (2009 \\
\hline UBC 811 & (GA) $8 \mathrm{C}$ & 53 & 43.3 & $\begin{array}{l}\text { Lakshmanan et al. (2007); Das et al. (2018); Surabhi and Pttanayak } \\
\text { (2015); Rout et al. (2009) }\end{array}$ \\
\hline UBC 812 & $(\mathrm{GA}) 8 \mathrm{~A}$ & 47 & 45 & Das et al. (2018); Surabhi and Pttanayak (2015); Rout et al. (2009 \\
\hline UBC 818 & (CA) $8 \mathrm{G}$ & 53 & 52 & Lamere and Rao (2015); Surabhi and Pttanayak (2015) \\
\hline UBC 820 & $(\mathrm{GT}) 8 \mathrm{~T}$ & 47 & 45 & Lakshmanan et al. (2007) \\
\hline UBC 825 & (AC) $8 \mathrm{C}$ & 53 & 47 & $\begin{array}{l}\text { Lakshmanan et al. (2007); Poerba and Ahmad (2010); Lamere and Rao } \\
\text { (2015) }\end{array}$ \\
\hline UBC 826 & $(\mathrm{AC}) 8 \mathrm{~T}$ & 47 & 49 & Surabhi and Pttanayak (2015); Lamere and Rao (2015); Rout et al. (2009) \\
\hline UBC 834 & (AG) $8 Y \mathrm{~T}$ & 44 & 50 & $\begin{array}{l}\text { Lakshmanan et al. (2007); Poerba and Ahmad, (2010); Das et al. (2018); } \\
\text { Lamere and Rao (2015); Surabhi and Pttanayak (2015) }\end{array}$ \\
\hline UBC 835 & $(\mathrm{AG}) 8 \mathrm{YC}$ & 50 & 50 & Das et al. (2018); Lamere and Rao (2015) \\
\hline UBC 840 & (GA)8YT & 44 & 53 & $\begin{array}{l}\text { Das et al. (2018); Lamere and Rao, (2015); Surabhi and Pttanayak } \\
\text { (2015); Lu et al. (2011) }\end{array}$ \\
\hline UBC 841 & $(\mathrm{GA}) 8 \mathrm{YC}$ & 50 & 46 & Das et al. (2018); Surabhi and Pttanayak, (2015); Lu et al. (2011 \\
\hline UBC 843 & (CT)8RA & 44 & 47 & Lamere and Rao (2015) \\
\hline UBC 848 & (CA) $8 \mathrm{RG}$ & 50 & 51 & Lamere and Rao (2015); Lu et al. (2011) \\
\hline UBC 855 & (AC)8YT & 44 & 60 & Lamere and Rao (2015); Lu et al. (2011) \\
\hline UBC 868 & (GAA)6 & 33 & 48 & Lamere and Rao (2015); Surabhi and Pattanayak (2015) \\
\hline
\end{tabular}




\section{RESULTS AND DISCUSSION}

\section{ISSR marker analysis}

A total of 15 ISSR primers employed in this study showed that only 14 primers produced reliable, clearly distinct and reproducible banding patterns. These amplified bands were scored and calculated for the polymorphic and monomorphic loci. These 14 ISSR primers produced a total of 133 loci with the size ranging from approximately 200 to 2500 bp (Fig. 1; Table 3). The number of loci per primer resulted from these ISSR primers was ranged from 2 to 14 loci with an average of 9.5 loci per primer. Primer UBC 855 produced the highest number of loci i.e., 14 loci, while primer UBC 848 generated the lowest number of loci $(2$ loci). The ISSR marker employed in this study resulted in very high polymorphic loci, in which from a total of 133 loci scored, $98.98 \%$ loci were polymorphic and only $1.02 \%$ of them were monomorphic. The average number of polymorphic loci per primer was 9.43 .

ISSR primers used in this study produced very high PIC value ranged from 0.60 to 0.91 per primer with an average of 0.80 per primer (Table 3 ). The highest PIC value was showed by UBC 818 and UBC 841 (0.91), whereas the lowest value was reached by UBC 834 primer (0.60). These results indicate that the ISSR primers used in this study are very effective to produce the polymorphisms of the banana accessions. The EMR values of all primers were very high and ranged from 2.00 to 14.00 . The values were almost the same from the total number of polymorphic loci (TL) since almost all of the primers produced $100 \%$ polymorphic loci (Table 3), showing the effectiveness of
ISSR primers in producing polymorphic bands for genetic variation analysis in banana cultivars used in this study. The values of marker index were very high ranging from 1.62 to 11.48 per primer. The average MI value was 7.58 per primer, in which the primer UBC 855 produced the highest MI value (11.48 per primer) and UBC 848 resulted in the lowest (1.62 per primer). These indicate the high variations among the individuals and the power of the ISSR marker for detecting variations and diversity among banana cultivars.

\section{Similarity analysis}

The similarity coefficient obtained from the ISSR DNA-markers was broadly ranged from 0.42 to 0.81 (Table 4). The lowest coefficient (0.42) was the similarity between Klutuk and Mauli banana and the highest (0.81) was shown between Kapas and Tembaga banana. The broad range of the similarity coefficient showed the high genetic diversity among banana cultivar employed in this study. A high similarity was also showed between Rutai and Susu (0.80), Kepok and Awak (0.77), Raja and Rutai (0.73), Kepok and Raja (0.71), as well as Raja and Susu (0.71) banana (Table 4). Furthermore, the lowest similarity coefficient has also appeared between Liar and Talas (0.51), Mauli and Talas (0.52), Klutuk and Liar (0.53), Klutuk and Tanduk (0.53), Raja and Tembaga (0.54), Klutuk and Talas (0.55). The similarity coefficient based on the ISSR markers needs to be confirmed with the morphological data to look at the effect of genetic material to the plant performances and phenotypes.

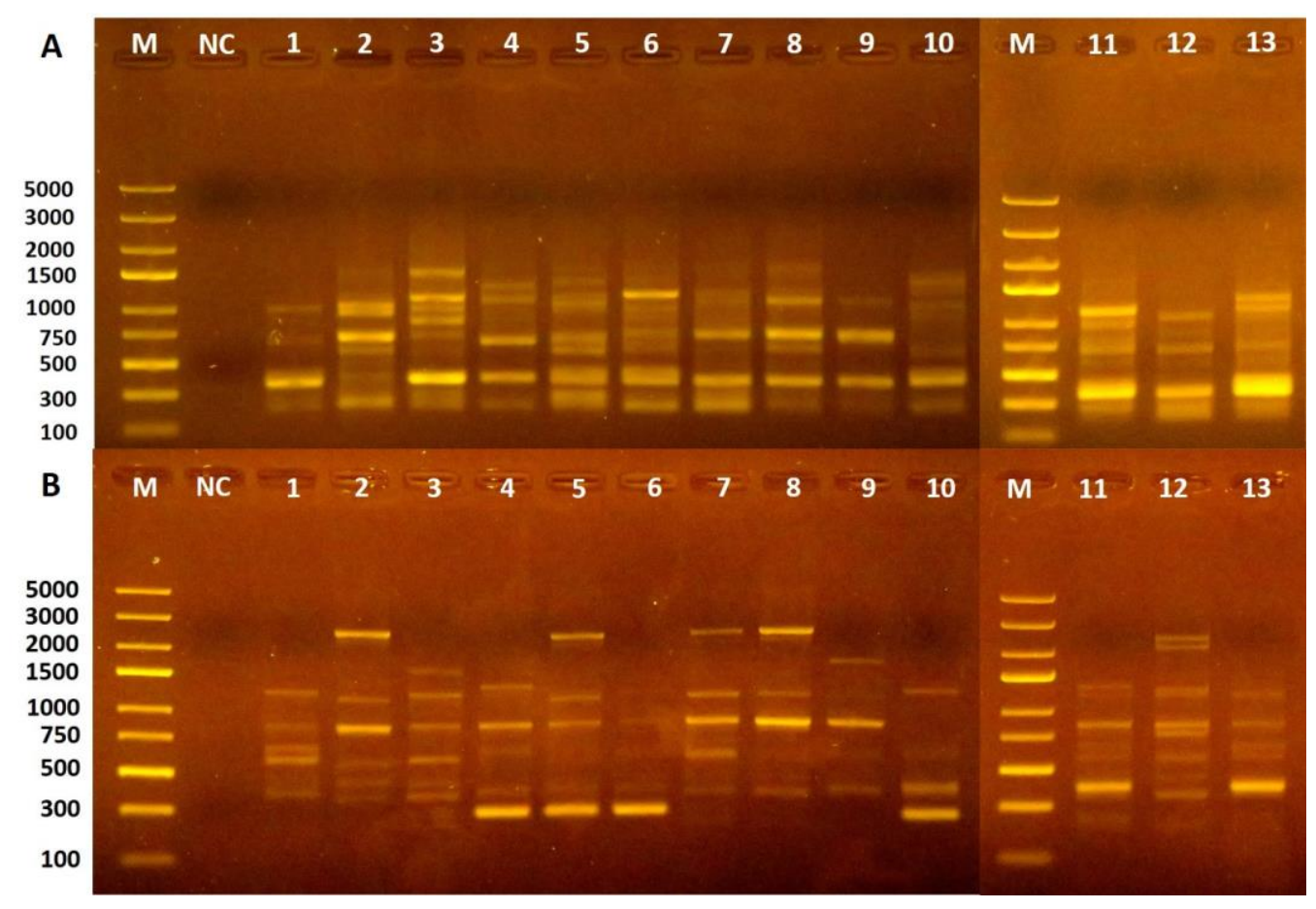

Figure 1. An ISSR DNA marker profile of thirteen banana cultivars from East Kalimantan using primer UBC 834 (A) and UBC 855 (B). (M) DNA marker, (NC) Negative control, (1) Ambon, (2) Klutuk, (3) Liar, (4) Mauli, (5) Raja, (6) Rutai, (7) Susu, (8) Awak, (9) Kepok, (10) Talas, (11) Kapas, (12) Tanduk, (13) Tembaga 
Table 3. Amplified sequence data of PCR amplification using ISSR markers among banana cultivars from East Kalimantan. ML (Monomorphic Loci), PL (Polymorphic Loci), PL (Percentage of Polymorphic Loci), PIC (Polymorphic Information Content), EMR (Effective Multiplex Ratio), and MI (Marker Index)

\begin{tabular}{|c|c|c|c|c|c|c|c|}
\hline Primer name & ML & PL & $\mathbf{T L}$ & PL\% & PIC & EMR & MI \\
\hline UBC 808 & 0 & 5 & 5 & 100 & 0.82 & 5.00 & 4.10 \\
\hline UBC 811 & 0 & 13 & 13 & 100 & 0.87 & 13.00 & 11.31 \\
\hline UBC 812 & 0 & 8 & 8 & 100 & 0.75 & 8.00 & 6.00 \\
\hline UBC 818 & 0 & 11 & 11 & 100 & 0.91 & 11.00 & 10.01 \\
\hline UBC 820 & 0 & 10 & 10 & 100 & 0.84 & 10.00 & 8.40 \\
\hline UBC 825 & 1 & 6 & 7 & 85.71 & 0.63 & 5.14 & 3.24 \\
\hline UBC 826 & 0 & 12 & 12 & 100 & 0.82 & 12.00 & 9.84 \\
\hline UBC 834 & 0 & 10 & 10 & 100 & 0.60 & 10.00 & 6.00 \\
\hline UBC 835 & 0 & 11 & 11 & 100 & 0.79 & 11.00 & 8.69 \\
\hline UBC 841 & 0 & 10 & 10 & 100 & 0.91 & 10.00 & 9.10 \\
\hline UBC 843 & 0 & 8 & 8 & 100 & 0.86 & 8.00 & 6.88 \\
\hline UBC 848 & 0 & 2 & 2 & 100 & 0.81 & 2.00 & 1.62 \\
\hline UBC 855 & 0 & 14 & 14 & 100 & 0.82 & 14.00 & 11.48 \\
\hline UBC 868 & 0 & 12 & 12 & 100 & 0.79 & 12.00 & 9.48 \\
\hline Total & 1 & 132 & 133 & 1385.71 & 11.22 & 131.14 & 106.14 \\
\hline Average & 0.07 & 9.43 & 9.5 & 98.98 & 0.80 & 9.37 & 7.58 \\
\hline
\end{tabular}

\section{Genetic relationships of banana cultivars based on the ISSR cluster analysis}

The genetic relationships among 13 genotypes comprising of three wild and ten cultivated bananas (Table 1) represented by a dendrogram designed using UPGMA with SAHN analysis of the ISSR markers were successfully conducted (Fig. 2). Cluster analysis based on the ISSR data-based generated four major clusters (Fig. 2). The first cluster was composed of five banana genotypes i.e., Ambon, Kapas, Tembaga, Liar and Tanduk. The second cluster comprised of one cultivar (Mauli banana). Six banana varieties, i.e., Raja, Rutai, Susu, Awak, Kepok, and Talas composed of the third cluster. The last cluster was Klutuk banana. Interestingly, Klutuk and Mauli were separated from other bananas. Based on the dendrogram, the farthest distance of the genetic relationships among bananas used in this study was between Ambon and Klutuk bananas; on the other hand, the closest relationship was observed between Kapas and Tembaga (Fig 2). The other interesting results have appeared in the dendrogram between Rutai and Susu bananas and also between Kepok and Awak showing close relationships with similarity coefficient of 0.80 and 0.77 , respectively. Talas banana, one of the superior local bananas from East Kalimantan besides Rutai banana, was included in the third group but more separated to other group members such as Raja, Rutai, Susu, Awak, and Kepok (Fig. 2). Results of the cluster analysis indicate that the ISSR marker analysis placed banana cultivars in relatively high diversity and variations with low similarity.

\section{Discussion}

Borneo Island is one of the centers of plant biodiversity in Indonesia including banana, but the comprehensive research about the diversity, potential and genetic resources of this plant are still very limited. The identification and characterization of banana varieties in Borneo island especially in East Kalimantan are very urgent for many purposes such as genetic conservation, breeding program, and socio-economic and cultural significance elucidation while the genetic erosion due to the land conversion, mining, and forest fire are increasing in recent years.

The morphological identification and genome classification of two local cultivars (Talas and Rutai banana) compared to other wild and cultivated bananas were reported (Sunaryo et al. 2017; 2019). The wild banana used in this study, i.e., Liar, Klutuk, and Awak were reported to have $\mathrm{AA}, \mathrm{BB}$, and $\mathrm{ABB}$ genome, subsequently; whereas the cultivated bananas i.e., Ambon, Kapas, Tanduk, Raja, Susu, Rutai, Talas, Mauli, and Kepok were reported as $\mathrm{AAA}, \mathrm{AAA}, \mathrm{AB}, \mathrm{AAB}, \mathrm{AAB}, \mathrm{AAB}, \mathrm{AAB}$, $\mathrm{AAB}, \mathrm{AAB}, \mathrm{AAB}$, and $\mathrm{ABB}$ genome (Table 1). Ambon, Raja, Kepok, Kapas, Susu, Tanduk, Tembaga and Mauli bananas are commercially cultivated in East Kalimantan and the origin of these varieties is still unclear since their existence is throughout Indonesian islands. Plant material exchange of these cultivars from or to other islands in Indonesia is very common and intensive. On the other hand, Talas and Rutai were identified as superior local cultivars with unique taste and good fruit performance; however, they are still not intensively cultivated (Sunaryo et al. 2019). The genetic relationships of the wild, local and commercially cultivated bananas are very interesting to reveal the genetic transfer and exchange among them and to look for the contribution of the wild cultivars to the commercially cultivated cultivars.

ISSR DNA-marker used in this study was very effective and powerful to detect and discriminate the polymorphisms among cultivars from East Kalimantan. This is supported by very high percentage of polymorphism, Polymorphism Information Content (PIC), Effective Multiplex Ratio (EMR), and Marker Index (MI) values (Table 3). The average of polymorphic loci percentage was very high about $98.98 \%$ with almost all of primers produced $100 \%$ polymorphic loci. This result was significantly higher than 
other reports using ISSR marker for genetic study in banana such as reported by Silva et al (2017) producing 97.5\%, Lamare, and Rao (2015) $87.58 \%$, Lu et al (2011) $85.1 \%$, and Das et al (2018) $53.83 \%$ of polymorphic loci. The PIC value, represents the power of the marker to discriminate among cultivars, which were found very high ranging from 0.61 to 0.91 with an average of 0.80 . The PIC values more than 0.50 represent multiple alleles influencing the markers and the maximum PCI value for dominant marker is 0.5 (Chesnokov and Artemyeva 2015). The average of EMR and MI values was also very high at about 9.37 and 7.58, respectively. The higher the EMR and MI values, the higher the usefulness and better method are (Chesnokov and Artemyeva 2015). The high EMR and MI values were reached by the ISSR primer UBC 855 , UBC 811 and UBC 818, on the other hand, the low values have belonged to UBC 848, UBC 825 and UBC 808 (Table 3). The EMR and MI values of the ISSR primers were varied depending on the plant genotype. Primer UBC 855 showed high EMR and MI values in Musa spp in this research and Lamare and Rao (2015), but it showed low performance in Ocimum spp. (Kumar et al. 2016). In addition, UBC 811 primer showed high EMR and MI values in this current study and low value in a study conducted by Ismail et al. (2019) in Torch Ginger plant; while primer UBC 808 showed low values in both of studies. Other primers showing low EMR and MI value, UBC 825 and UBC 848 in this study were consistently low or contrarily in Ocimum spp genetic analysis (Kumar et al. 2016). All taken together, the ISSR marker showed a powerful and effective to discriminate the banana cultivars from East Kalimantan. The primer UBS 855 , UBC 818 and UBC 811 showed the best marker performances compared to other ISSR primers used in this study.

The similarity coefficient based on the ISSR marker was ranged from 0.42 to 0.81 (Table 4). The value of similarity coefficient will influence the genetic relationships among the cultivars. The highest value of similarity coefficient was showed in between Kapas and Tembaga banana with the coefficient of 0.81 . Only a few articles reported Kapas and Tembaga banana study, therefore the comparison of morphological characters of these bananas to other banana is also limited. From this study, it is clear that Kapas and Tembaga banana have very high similarity. It suggests that both bananas might have the same ancestor and genome. The other interesting finding is a high similarity between Rutai and Susu banana (0.80) based on the ISSR marker profile (Table 4), although the morphological study of these bananas showed very low similarity (Sunaryo et al. 2019). Awak and Kepok banana were also much closed related to the similarity index of 0.77 . The other study using Awak and Kepok banana originated from West Jawa Province showed that they were classified in a cluster/group and also much closed related (Wahyuningtyas et al. 2009; Poerba and Ahmad 2010).

The dendrogram generated from ISSR markers showed that the farthest genetic distance was observed between Ambon (AAA genome) and Klutuk banana (BB genome) (Fig. 2). This finding is in line with the fact that Ambon is a triploid banana containing three A genome derived from Musa acuminata, the ancestor of sweet banana, and Klutuk is the B genome ancestor, Musa balbisiana (Sunaryo et al. 2019). Many reports placed Musa species with AA/AAA genome in the farthest genetic distance with $\mathrm{BB} / \mathrm{BBB}$ genome (De Langhe et al. 2010; Li et al. 2013; Perrier et al. 2019).

The dendrogram classified all cultivars used in this study into 4 main clusters/groups (Fig. 2). First group placed Ambon, Kapas, Tembaga, Liar and Tanduk banana in the same cluster. The genome group classification showed that Ambon possesses AAA genome, Liar AA genome, Tanduk AB genome (Sunaryo et al. 2019), and Kapas AAB genome (Wahyuningtyas et al. 2009). There was no report showing Tembaga genome. The close relation between Kapas and Tembaga with Ambon strongly indicates that the genome of both banana cultivars (Kapas and Tembaga) is also AAA. They (Kapas, Tembaga, and Ambon) were also closed related to Liar banana (AA genome) that was identified as a diploid banana showing prominent characters of Musa acuminate (Sunaryo et al. 2019).

Table 4. Qualitative similarity (SimQual) coefficient based on the Simple Matrix method (SM) of the ISSR analysis in 13 Banana varieties from East Kalimantan, Indonesia

\begin{tabular}{|c|c|c|c|c|c|c|c|c|c|c|c|c|c|}
\hline Varieties & Ambon & Klutuk & Liar & Mauli & Raja & Rutai & Susu & Awak & Kepok & Talas & Kapas & Tanduk & Tembaga \\
\hline Ambon & 1.00 & & & & & & & & & & & & \\
\hline Klutuk & 0.60 & 1.00 & & & & & & & & & & & \\
\hline Mauli & 0.64 & 0.42 & 0.64 & 1.00 & & & & & & & & & \\
\hline Raja & 0.69 & 0.63 & 0.66 & 0.66 & 1.00 & & & & & & & & \\
\hline Rutai & 0.68 & 0.58 & 0.63 & 0.67 & 0.73 & 1.00 & & & & & & & \\
\hline Awak & 0.69 & 0.61 & 0.56 & 0.61 & 0.68 & 0.69 & 0.71 & 1.00 & & & & & \\
\hline Kepok & 0.71 & 0.61 & 0.60 & 0.61 & 0.71 & 0.68 & 0.68 & 0.77 & 1.00 & & & & \\
\hline Talas & 0.65 & 0.55 & 0.51 & 0.52 & 0.65 & 0.66 & 0.69 & 0.62 & 0.68 & 1.00 & & & \\
\hline Kapas & 0.73 & 0.60 & 0.69 & 0.59 & 0.56 & 0.69 & 0.63 & 0.60 & 0.63 & 0.63 & 1.00 & & \\
\hline Tanduk & 0.62 & 0.53 & 0.63 & 0.58 & 0.62 & 0.63 & 0.63 & 0.59 & 0.57 & 0.56 & 0.66 & 1.00 & \\
\hline Tembaga & 0.66 & 0.58 & 0.63 & 0.60 & 0.54 & 0.62 & 0.57 & 0.56 & 0.56 & 0.56 & 0.81 & 0.66 & 1.00 \\
\hline
\end{tabular}




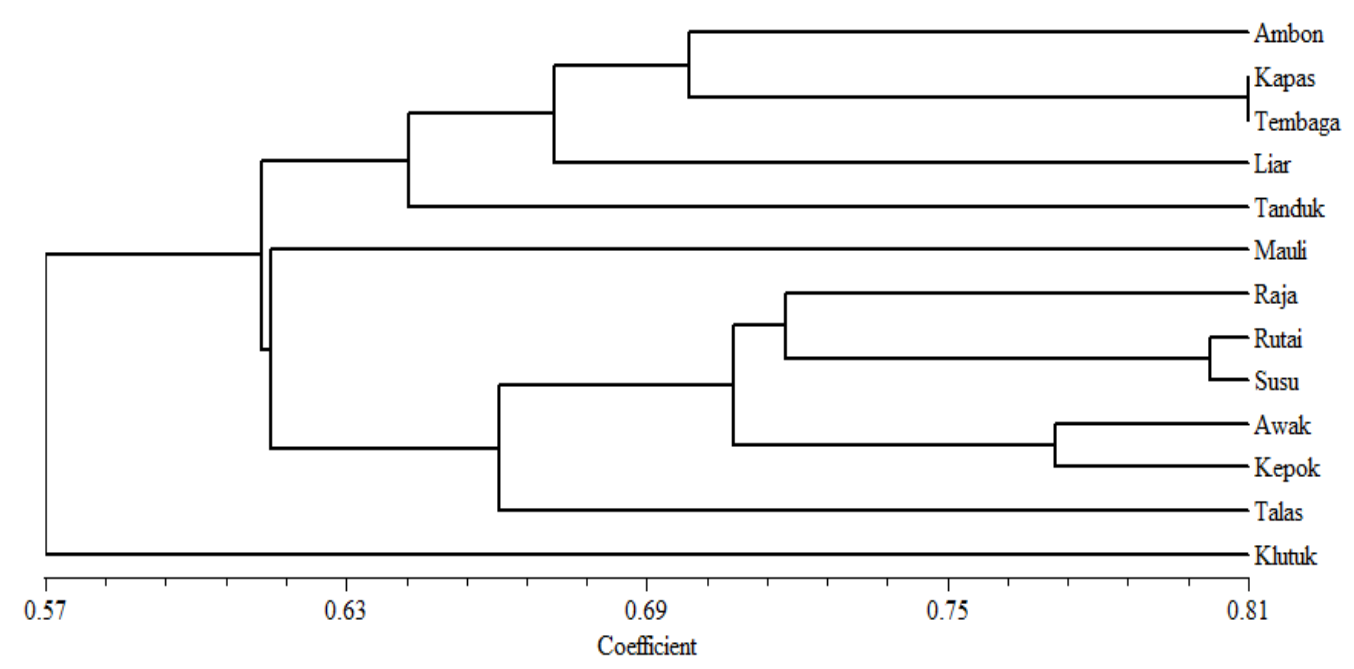

Figure 2. Genetic relationships of wild and cultivated bananas from East Kalimantan using UPGMA cluster analysis based on the similarity coefficient of the ISSR markers.

This finding proposes a new genome identification and classification especially for Kapas and Tembaga to have AAA genome. Furthermore, Tanduk banana appeared in the same cluster with this group (Ambon, Kapas, tembaga, and Liar). Based on morphological character classification, Tanduk banana was varied in genome grouping because many of its key characters determining the genome group are ambiguous (Sunaryo et al. 2019). It was grouped in AB genome (Sunaryo et al. 2019), AAB genome (Retnoningsih et al. 2014; Fitriyah et al. 2017), and ABB genome (Wahyuningtyas et al. 2009). The result of cluster analysis based on ISSR marker placed Tanduk banana in a closed relationship with the A genome-group cluster. It strongly indicates that Tanduk banana is very possible to have more A genome such as $\mathrm{AAB}$ genome and it makes a correction for the result of genome classification using morphological characters (Sunaryo et al. 2019). The fact that the second cluster composed of only one cultivar i.e., Mauli banana and was separated from other groups was very surprising (Fig. 2). Based on the morphological characters and SSR marker Mauli banana originated from West Java, it was always grouped in triploid banana with genome structure of AAA (Wahyuningtyas et al. 2009) or AAB (Retnoningsih et al. 2014). In this study, Mauli was positioned in between the first cluster (AA/AAA genome) and the third cluster ( $\mathrm{AAB} / \mathrm{ABB}$ genome) but it was very closely related to the third cluster, indicating that Mauli banana might have $A A B$ or $\mathrm{ABB}$ genome rather than $\mathrm{AA} / \mathrm{AAA}$ genome.

Raja, Rutai, Susu, Awak, Kepok, and Talas banana composed of the third cluster (Fig. 2). Interesting finding showed that Rutai banana, one of the local cultivar originated from East Kalimantan was much closed related to Susu banana a commercially cultivated banana. They were also closed related to Raja banana, another commercially cultivated banana. The genome classification showed that they (Rutai, Susu, and Raja banana) were grouped into AAB banana. They were also classified as sweet/dessert banana. Awak and Kepok banana were much closed related according to ISSR marker analysis (Fig. 2). Both of bananas were classified as $\mathrm{ABB}$ genome and cooking banana (Orjeda 2000; Lim 2012). These facts indicate that Rutai and Susu or Awak and Kepok banana might be originated from the same ancestor derived from natural genetic mutation/alteration or hybrids. Talas banana, another local banana originated from East Kalimantan, was grouped in the same cluster with the AAB and ABB bananas (Fig 2), giving confirmation that Talas banana was also AAB or ABB genome. The morphological characterization reported that Talas banana can be used as dessert or cooking banana and it was grouped as AAB banana (Sunaryo et al. 2019). The variation of banana cultivars in nature is caused by natural hybrids or by genetic mutations. Triploid bananas, the origin of modern banana, could occur in nature due to the natural somatic mutations or the cross-pollination between diploid clones producing $2 n$ gametes and diploid clone producing $n$ gamete (Bakry et al. 2009). The cross-pollinations could be happened between Musa acuminata (AA) and Musa balbisiana (BB) or even with other Musa spp. This natural genetic changes and hybrids producing various combinations and new mutants of bananas generated many modern and edible bananas.

In this research, Klutuk banana composed of the fourth cluster with long genetic distance from other clusters (Fig. 2). Klutuk was classified as BB genome (Sunaryo et al. 2019; Fitriyah et al. 2017) and known as Musa balbisiana species, the donor of $\mathrm{B}$ genome for many cooking bananas (AAB, ABB, ABBB, or $\mathrm{ABBB}$ ). Unsurprisingly, Klutuk banana was placed in the farthest genetic distance with other groups as it is one of modern banana ancestors with pure B genome structure. The same result of genetic relationships for Klutuk (Musa balbisiana) banana was also reported (De Langhe et al. 2010; Li et al. 2013; Perrier et al. 2019). 
In conclusion, the wild bananas (Liar and Klutuk) were the ancestor of cultivated bananas since they contributed for $\mathrm{A}$ and $\mathrm{B}$ genome to generate many triploids and cultivated bananas. Awak banana, other wild banana, was closely related to Kepok banana, a commercial cooking banana. Rutai banana, a local cultivar from East Kalimantan, was strongly related to Susu banana indicating that they are from the same parent. Kapas and Tembaga banana, other cultivated banana was much closed related and there is strong indication that they have the same genome (AAA). Talas banana was much closed related to the AAB genome such as Raja, Rutai, Susu or ABB genome such as Awak and Kepok. Mauli banana, the commercially cultivated banana appeared closer to AAB or ABB genome.

\section{ACKNOWLEDGEMENTS}

We would like to thank Hibah STRANAS for the year 2016-2018 research project, Ministry of Research, Technology and Higher Education, Republic of Indonesia which financially supported this research.

\section{REFERENCES}

Anand G, Kapoor R. 2018. Population structure and virulence analysis of Alternaria carthami isolates of India using ISSR and SSR markers. World J Microbiol Biotechnol 34 (9): 140.

Bakry F, Carreel F, Jenny C, Horry JP. 2009. Genetic improvement of Banana. In: Jain SM, Priyadarshan PM (eds). Breeding Plantation Tree Crops: Tropical Species. Springer Science+Business Media, New York.

Brown A, Tumuhimbise R, Amah D, Uwimana B, Nyine M, Mduma H, Talengera D, Karamura D, Kuriba J, Swennen R. 2017. Bananas and Plantains (Musa spp.). In: Campos H, Caligari PDS (eds). Genetic Improvement of Tropical Crops. Springer International Publishing, New York.

Chesnokov YV, Artemyeva AM. 2015. Evaluation of the measure of polymorphism information of genetic diversity. Agric Biol 50 (5) 571-578

Cui C, Li Y, Liu Y, Li X, Luo S, Zhang Z, Wu R, Liang G, Sun J, Peng J, Tian P. 2017. Determination of genetic diversity among Saccharina germplasm using ISSR and RAPD markers. C R Biol 340 (2): 76-86.

De Langhe E, Hribova E, Carpentier S, Dolezel J, Swennen R. 2010. Did backcrossing contribute to the origin of hybrid edible bananas? Ann Bot 106: 849-857.

Das SC, Balamohan T, Poornima K, Van Den Bergh. 2018. Evaluation of genetic diversity in some banana hybrids using ISSR markers. Intl J Curr Microbiol App Sci 7 (1): 146-157.

Doyle JJ, Doyle JL. 1987. A rapid DNA isolation procedure for small quantities of fresh leaf tissue. Phytochem Bull (19): 11-15.

Fitriyah A, Ariyanti EE, Damanhuri, Kuswanto. 2017. Grouping of 30 cultivars of banana (Musa spp.) based on genome and genetic relationships. J Produksi Pertanian 5 (4): 568-575. [Indonesian]

Gebrehiwet M, Haileselassie T, Gadissa F, Tesfaye K. 2019. Genetic diversity analysis in Plectranthus edulis (Vatke) Agnew populations collected from diverse geographic regions in Ethiopia using intersimple sequence repeats (ISSRs) DNA marker system. J Biol ResThessaloniki 26 (7): 1-11.

Ghimire BK, Yu CY, Kim SH, Chung IM. 2019. Assessment of diversity in the accessions of Setaria italica L. based on phytochemical and morphological traits and ISSR Markers. Molecules 24: 1-24.

Gu HR, Wan YF, Yang Y, Ao Q, Cheng WL, Deng SH, Pu DY, He XF, Jin L, Wang ZJ. 2019. Genetic and morphology analysis among the pentaploid $\mathrm{F}_{1}$ hybrid fishes (Schizothorax wangchiachii + $\times$ Percocypris pingi $\widehat{\jmath}$ ) and their parents. Animal 13 (12): 2755-2764.
Ismail NA, Rafii MY, Mahmud TMM, Hanafi MM, Miah G. 2019. Genetic diversity of Torch ginger (Etlingera elatior) germplasm revealed by ISSR and SSR Markers. BioMed Res Intl 2019: 5904804. DOI: $10.1155 / 2019 / 5904804$.

Jasso-Martınez JM, Machkour-MRabet S, Vila R, Rodrıguez-Arnaiz R, Castañeda-Sortibran AN. 2018. Molecular evidence of hybridization in sympatric populations of the Enantia jethys complex (Lepidoptera: Pieridae). PLoS ONE 13 (5): e0197116. DOI: 10.1371/journal.pone.0197116.

Kandan A, Akhtar J, Singh B, Pal D, Chand D, Rajkumar S, Agarwal PC. 2016. Genetic diversity analysis of fungal pathogen Bipolaris sorghicola infecting Sorghum bicolor in India. J Environ Biol 37 (6): 1323-1330.

Kumar A, Mishra P, Baskaran K, Shukla AK, Shasany AK, Sundaresan V. 2016. Higher efciency of ISSR markers over plastid $p s b A$-trnH region in resolving taxonomical status of genus Ocimum L. Ecol Evol 6: 7671-7682.

Lakshmanan V, Venkataramareddy SR, Neelwarne B. 2007. Molecular analysis of genetic stability in long-term micropropagated shoots of banana using RAPD and ISSR markers. Electron J Biotechnol 10 (1): 1-8.

Lamare A, Rao SR. 2015. Efficacy of RAPD, ISSR and DAMD markers in assessment of genetic variability and population structure of wild Musa acuminata colla. Physiol Mol Biol Plants 21 (3): 349-358.

Li LF, Wang HY, Cui Zhang C, Wang XF1, Shi FX, Chen WN, Ge XJ. 2013. Origins and domestication of cultivated banana inferred from chloroplast and nuclear genes. PLoS ONE 8 (11): e80502. DOI: 10.1371/journal.pone.0080502.

Lim TK. 2012. Edible Medicinal and Non-Medicinal Plants Vol. 3. Fruits. Springer, New York.

Lu Y, Zhang X, Pu J, Qi Y, Xie Y. 2011. Molecular assessment of genetic identity and genetic stability in banana cultivars (Musa spp.) from China using ISSR markers. AJCS 5 (1): 25-31.

Manzo-Sánchez G, Buenrostro-Nava MT, Guzmán-González S, OrozcoSantos M, Youssef M, Medrano RMEG. 2015. Genetic diversity in bananas and plantains (Musa spp.). In: Caliskan M, Cevahir Oz G, Kavakli IH, Ozcan B (eds.). Molecular approaches to genetic diversity. IntechOpen, London.

Marimutu Somasundaram S, Subbaraya U, Durairajan SG, Rajendran S, Gopalakrishnan J, Shahul Hameed B, Palani D, Suthanthiram B. 2019. Comparison of two different electrophoretic methods in studying the genetic diversity among plantains (Musa spp.) using ISSR markers. Electrophoresis 40 (9): 1265-1272.

Mitina G, Kazartsev I, Vasileva A, Yli-Mattila T. 2017. Multilocus genotyping based species identification of entomopathogenic fungi of the genus Lecanicillium (Verticillium lecanii S.L.). J Basic Microbiol 57 (11): 950-961.

Mohammadi A, Bahramikia S. 2019. Molecular identification and genetic variation of Alternaria species isolated from tomatoes using ITS1 sequencing and inter simple sequence repeat methods. Curr Med Mycol 5 (2): 1-8.

Ng WL, Tan SG. 2015. Inter-Simple Sequence Repeat (ISSR) markers: Are we doing it right? ASM Sci J 9 (1): 30-39.

Orjeda G. 2000. Evaluating bananas: A global partnership: Result of IMTP phase II. INIBAB, France.

Pérez de Rosas AR, Restelli MF, Fernández CJ, Blariza MJ, García BA. 2017. Application of Inter-Simple Sequence Repeat Markers in the analysis of populations of the Chagas disease vector Triatoma infestans (Hemiptera, Reduviidae). Am J Trop Med Hyg 96 (3): 660663.

Perrier X, Jenny C, Bakry F, Karamura D, Kitavi M, Dubois C, Hervouet C, Philippson G, De Langhe E. 2019. East African diploid and triploid bananas: a genetic complex transported from South-East Asia. Ann Bot 123 (1): 19-36.

Poerba YS, Ahmad F. 2010. Genetic variability among 18 cultivars of cooking bananas and plantains by RAPD and ISSR markers. Biodiversitas 11 (3): 118-123.

Reddy MP, Sarla N, Siddiq EA. 2002. Inter simple sequence repeat (ISSR) polymorphism and its application in plant breeding. Euphytica 128: 9-17.

Retnoningsih A, Megia R. Hartana A. 2014. Phylogenetic relationships of Indonesian banana cultivars inferred from TrnH-F intergenic spacer of chloroplast DNA. Floribunda 4 (8): 202-211.

Rohlf FJ. 1998. NTSys-pc: numerical taxonomy and multivariate analysis system, version 2.02. Exter Software, Setauket. 
Rout GR, Senapati SK, Aparajita S, Palai SK. 2009. Studies on genetic identification and genetic fidelity of cultivated banana using ISSR markers. Plant Omics J 2 (6): 250-258.

Sehgal D, Rajpal VR, Raina SN, Sasanuma T, Sasakuma T. 2009. Assaying polymorphism at DNA level for genetic diversity diagnostics of the safflower (Carthamus tinctorius L.) world germplasm resources. Genetica 135: 457-470.

Silva AV, Nascimento AL, Vitória MF, Rabbani AR, Soares AN, Lédo AS. 2017. Diversity and genetic stability in banana genotypes in a breeding program using inter simple sequence repeats (ISSR) markers. Genet Mol Res 16 (1): 1-9.

Sunaryo W, Nurhasanah, Rahman, Sugiarto A. 2017. Identification and characterization of Talas banana, a superior local cultivar from East Kalimantan (Indonesia), based on morphological and agronomical characters. Biodiversitas 18 (4): 1414-1423.
Sunaryo W, Mulyadi A, Nurhasanah. 2019. Genome group classification and diversity analysis of Talas and Rutai banana, two local cultivars from East Kalimantan, based on morphological characters. Biodiversitas 20 (8): 2355-2367.

Varshney RK, Chabane K, Hendre PS, Aggarwal RK, Graner A. 2007. Comparative assessment of EST-SSR, EST-SNP and AFLP markers for evaluation of genetic diversity and conservation of genetic resources using wild, cultivated and elite barleys. Plant Sci 173 (6): 638-649.

Venkatachalam L, Sreedhar RV, Bhagyalakshmi N. 2008. The use of genetic markers for detecting DNA polymorphism, genotype identification and phylogenetic relationships among banana cultivars. Mol Phylogenet Evol 47 (3): 974-985.

Wahyuningtyas W, Retnoningsih A, Rahayu ES. 2009. Genetic biodiversity of banana with B genome using microsatellite marker. Biosaintifika 1 (1): 1-10. [Indonesian] 